\title{
Automatic 1D integrated geophysical modelling of lithospheric discontinuities: a case study from Carpathian-Pannonian Basin region
}

\author{
Michal GRINČ ${ }^{1}$, Hermann ZEYEN ${ }^{2,3}$, Miroslav BIELIK ${ }^{1,4}$ \\ ${ }^{1}$ Geophysical Institute of the Slovak Academy of Sciences \\ Dúbravská cesta 9, 84528 Bratislava, Slovak Republic; e-mail: michal.grinc@gmail.com \\ 2 Département des Sciences de la Terre, Université Paris-Sud \\ Orsay, France; e-mail: hermann.zeyen@u-psud.fr \\ ${ }^{3}$ CNRS, UMR 8146, Orsay, France \\ ${ }^{4}$ Department of Applied and Environmental Geophysics, Faculty of Natural Sciences \\ Comenius University, Mlynská dolina, pav. G, 84248 Bratislava, Slovak Republic \\ e-mail: bielik@fns.uniba.sk
}

\begin{abstract}
Using a very fast 1D method of integrated geophysical modelling, we calculated models of the Moho discontinuity and the lithosphere-asthenosphere boundary in the Carpathian-Pannonian Basin region and its surrounding tectonic units. This method is capable to constrain complicated lithospheric structures by using joint interpretation of different geophysical data sets (geoid and topography) at the same time. The Moho depth map shows significant crustal thickness variations. The thickest crust is found underneath the Carpathian arc and its immediate Foredeep. High values are found in the Eastern Carpathians and Vrancea area $(44 \mathrm{~km})$. The thickest crust modelled in the Southern Carpathians is $42 \mathrm{~km}$. The Dinarides crust is characterized by thicknesses more than $40 \mathrm{~km}$. In the East European Platform, crust has a thickness of about $34 \mathrm{~km}$. In the Apuseni Mountains, the depth of the Moho is about $36 \mathrm{~km}$. The Pannonian Basin and the Moesian Platform have thinner crust than the surrounding areas. Here the crustal thicknesses are less than $30 \mathrm{~km}$ on average. The thinnest crust can be found in the SE part of the Pannonian Basin near the contact with the Southern Carpathians where it is only $26 \mathrm{~km}$. The thickest lithosphere is placed in the East European Platform, Eastern Carpathians and Southern Carpathians. The East European Platform lithosphere thickness is on average more than $120 \mathrm{~km}$. A strip of thicker lithosphere follows the Eastern Carpathians and its Foredeep, where the values reach in average $160 \mathrm{~km}$. A lithosphere thickness minimum can be observed at the southern border of the Southern Carpathians and in the SE part of the Pannonian Basin. Here, it is only $60 \mathrm{~km}$. The extremely low values of lithospheric thickness in this area were not shown before. The Moesian Platform is characterized by an $\mathrm{E}-\mathrm{W}$ trend of lithospheric thickness decrease. In the East,
\end{abstract}


the thickness is about $110 \mathrm{~km}$ and in the west it is only $80 \mathrm{~km}$. The Pannonian Basin lithospheric thickness ranges from 80 to $100 \mathrm{~km}$.

Key words: geothermics, gravity, geoid, topography, 1D integrated geophysical modelling, crust, lithosphere, Carpathian-Pannonian Basin region

\section{Introduction}

The lithosphere-asthenosphere boundary (LAB) may be defined in different ways, seismic, electric, mechanical or thermic. Modelling of the thermal lithospheric thickness is usually based on surface heat flow. However, an extrapolation of temperatures from a few $\mathrm{km}$ (usually less than this) to often more than $100 \mathrm{~km}$ is very uncertain, especially due to some disturbing and usually unknown near-surface effects like heat production distribution or paleoclimatic effects. Integration of multiple geophysical data that are based on temperature-dependent physical properties is necessary to constrain complicated lithospheric structures. In the example presented here, we used geoid and topography data that depend on temperature dependent rock densities. This approach offers an improved geophysical interpretation of lithospheric structures and has clear advantages over traditional kinds of interpretation of single data sets on their own.

One dimensional (1D) integrated geophysical modelling is a very fast method which allows us to establish a preliminary model of the Moho and LAB. As the Carpathian-Pannonian Basin region provides not only a very good occasion for studying its complex geological structure and tectonics but also very good geophysical constraints, we created a model of the Moho discontinuity and the LAB of this area and discuss the uncertainties of the method in the absence of good a priori knowledge.

\section{Methodology}

The 1D geophysical modelling approach was initially presented by Fullea et al. (2007). From a scientific point of view, it is 1D modelling and therefore only valid for large-scale structures but on the other hand, when doing this 
1D analysis on many vertical columns covering an area, it gives us a $3 \mathrm{D}$ initial estimate of the main boundaries that we are interested in the studied area (Grinč, 2013).

The method is based on the combination of elevation and geoid anomaly data to map crustal and lithospheric thickness. The geoid anomaly is defined as a residual short-wavelength component of the geoid undulations after removing its spherical harmonics up to degree and order 10. The reason for using different data sets is that each of these data sets is sensitive to different lithospheric phenomena. Topography reflects variations of the average density within the lithospheric column, whereas geoid anomaly depends on the depth distribution of density variations and is proportional to the dipole moment of density (Turcotte and Schubert, 1982). In this case, only two homogeneous layers are considered by us here: crust and lithospheric mantle. Topography is modelled in local isostasy, based on the assumption that the lithosphere floats freely on the asthenosphere and below a certain level of compensation, the pressure does not vary laterally (Lachenbruch and Morgan, 1990). The topography can be calculated as:

$\varepsilon=\frac{z_{c}\left(\rho_{m}-\rho_{c}\right)-z_{L}\left(\rho_{m}-\rho_{a}\right)-L_{0} \rho_{a}}{\rho_{c}-\rho_{w}}$,

where $\varepsilon$ is topography, $z_{c}$ is Moho depth ( $m$ with respect to sea level), $z_{L}$ is LAB depth ( $m$ with respect to sea level), $\rho_{c}$ the mean density of the crust $\left(\mathrm{kg} . \mathrm{m}^{-3}\right), \rho_{m}$ the mean density of the lithospheric mantle $\left(\mathrm{kg} \cdot \mathrm{m}^{-3}\right), \rho_{a}$ is density of the asthenosphere (taken as $3200 \mathrm{~kg} \cdot \mathrm{m}^{-3}$ and $L_{0}$ is a calibration constant corresponding to the depth of the free asthenosphere $(2380 \mathrm{~m}$ below sea level). Density in the crust can be optionally modelled with a constant vertical gradient, defined by the user, in order to simulate the density increase within the crust, mainly between sediments, upper and lower crust. In the mantle, the density varies linearly with depth due to the temperature increase with depth (see Eq. 3). This gradient depends on the lithosphere thickness and is calculated automatically by the program. The equation is valid for points above or below sea level. If elevation is above sea level $(\varepsilon>0)$, then $\rho_{w}=0$; if it is below sea level, $\rho_{w}=1030 \mathrm{~kg} . \mathrm{m}^{-3}$ is the density of sea-water. If local isostasy holds and the wavelengths of the lateral density contrasts are large enough with respect to their depth, i.e., the $1 \mathrm{D}$ approximation is suitable, then the geoid anomaly $(N)$, is pro- 
portional to the dipolar moment of the anomalous mass distribution (Fullea et al., 2005; Haxby and Turcotte, 1978; Ockendon and Turcotte, 1977; Turcotte and Schubert, 1982). For a two-layer model with a linear vertical density gradient, for crust and lithospheric mantle we can write (with a positive downward coordinate system, however taking topography positively upward):

$$
\begin{aligned}
N= & -\frac{2 \pi G}{g}\left[\int_{\varepsilon}^{Z c}\left(\rho_{c}(z)-\rho_{a}\right) z \mathrm{~d} z+\int_{Z c}^{Z_{L}}\left(\rho_{m}(z)-\rho_{a}\right) z \mathrm{~d} z\right]+N_{0} \quad \text { for } \varepsilon>=0 \\
N= & -\frac{2 \pi G}{g}\left[\int_{0}^{-\varepsilon}\left(\rho_{w}-\rho_{a}\right) z \mathrm{~d} z+\int_{-\varepsilon}^{Z c}\left(\rho_{c}(z)-\rho_{a}\right) z \mathrm{~d} z+\int_{Z c}^{Z_{L}}\left(\rho_{m}(z)-\rho_{a}\right) z \mathrm{~d} z\right]+ \\
& +N_{0} \quad \text { for } \varepsilon<0,
\end{aligned}
$$

where an integration constant $N_{0}$ is used to adjust the zero level of the geoid anomalies. In contrast to Fullea et al. (2006), we are not using absolute densities but density differences with respect to asthenosphere which simplifies the formula.

These two equations form a system of equations with five unknowns. Moho depth $\left(z_{c}\right)$, depth of LAB $\left(z_{L}\right)$, average density of crust $\left(\rho_{c}\right)$, density of lithospheric mantle $\left(\rho_{m}\right)$ and $N_{0}$ (the crustal density gradient, being optional and fixed by the user is not considered as unknown). Since there are five variables and only two constraints, here we fixed $\rho_{c}$ as known density with a known vertical gradient and calculate $\rho_{m}$ using a linear temperature gradient in the mantle based on the thermal expansion coefficient $\alpha$ $\left(\alpha=3.5 \times 10^{-5} \mathrm{~K}^{-1}\right)$ (Parsons and Sclater, 1977):

$\rho_{m}(T)=\rho_{a}\left[1+\alpha\left(T_{a}-T(z)\right)\right]$,

where $\mathrm{T}_{a}$ is the temperature at the $\mathrm{LAB}$ taken as $1300{ }^{\circ} \mathrm{C}$. The average mantle density is the mean of asthenospheric and Moho densities. In order to calculate the Moho density, we assume a simple thermal model with constant thermal conductivity and heat production in the upper and lower continental crust supposed to form each half of the total crust. In this case, we obtain for surface heat flow $\mathrm{q}_{\mathrm{s}}$ and Moho temperature $\mathrm{T}_{\text {Moho }}$ : 
$q_{s}=\frac{T_{a}-T_{s}+X_{1}\left(z_{c}+\varepsilon\right)^{2}+X_{2} \frac{\left(z_{c}+\varepsilon\right)}{2}\left(z_{L}-z_{c}\right)}{X_{3}\left(z_{c}+\varepsilon\right)+\frac{z_{L}-z_{c}}{C_{M}}}$

$T_{\text {Moho }}=T_{s}+X_{3} q_{s}\left(z_{c}+\varepsilon\right)-X_{1}\left(z_{c}+\varepsilon\right)^{2}$,

where $X_{i}$ are auxiliary variables:

$X_{1}=\frac{A_{U C}}{8 C_{U C}}+\frac{A_{U C}}{4 C_{L C}}+\frac{A_{L C}}{8 C_{L C}}$,

$X_{2}=\frac{A_{U C}+A_{L C}}{C_{M}}, \quad X_{3}=\frac{1}{2 C_{U C}}+\frac{1}{2 C_{L C}}$.

$A_{U C}$ is heat production in the upper crust (e.g. $2 \mu \mathrm{W} / \mathrm{m}^{3}$ ), $A_{L C}$ is heat production in the lower crust (e.g. $\left.0.2 \mu \mathrm{W} / \mathrm{m}^{3}\right), C_{U C}$ is thermal conductivity in the upper crust (e.g. $2.5 \mathrm{~W} /(\mathrm{m} \mathrm{K})), C_{L C}$ is thermal conductivity in the lower crust (e.g. $2 \mathrm{~W} /(\mathrm{mK})), C_{M}$ is thermal conductivity in the mantle (e.g. $3.3 \mathrm{~W} /(\mathrm{m} \mathrm{K})$ ) and $T_{S}$ is surface temperature (typically $10^{\circ} \mathrm{C}$ ). Heat production in the mantle is neglected. Introducing Eq. 3 and Eq. 4 into Eq. 2, we obtain for the geoid:

$$
\begin{aligned}
N= & -\frac{\pi G}{g}\left[C_{e}+f_{1}\left(z_{c}^{2}-\varepsilon^{2}\right)+f_{2}\left(z_{c}^{3}-|\varepsilon|^{3}\right)+\right. \\
& \left.+f_{3}\left(z_{L}^{2}+z_{L} z_{c}-2 z_{c}^{2}\right)\right]+N_{0},
\end{aligned}
$$

where $G$ is the universal gravitational constant, $g$ the surface gravitational attraction,

$$
\begin{aligned}
& C_{e}= \begin{cases}0 & \text { if } \varepsilon \geq 0 \\
\left(\rho_{w}-\rho_{a}\right) \varepsilon^{2} & \text { if } \varepsilon<0\end{cases} \\
& f_{1}=\left(\rho_{c}^{t o p}-\rho_{a}+\beta \varepsilon\right), \quad \beta=\frac{\left(\rho_{c}^{b o t}-\rho_{c}^{t o p}\right)}{z_{c}+\varepsilon}, \\
& f_{2}=\frac{2 \beta}{3}, \quad f_{3}=\frac{\rho_{a} \alpha\left(T_{a}-T_{\text {Moho }}\right)}{3}
\end{aligned}
$$


$\rho_{c}^{t o p}$ and $\rho_{c}^{b o t}$ are crustal densities at the surface and at the Moho respectively. The integration constant related to the reference level for geoid anomaly $N_{0}$ has to be defined empirically. The parameters $z_{c}$ and the $z_{L}$ can then be calculated.

\section{Study area and databases}

The coordinates of the study regions are $\left(17^{\circ} / 28^{\circ} \mathrm{E}-43^{\circ} / 51^{\circ} \mathrm{N}\right)$ so that the area includes the whole Carpathian-Pannonian Basin region and its surrounding tectonic units (Grinč, 2013). In the $\mathrm{N}$ and $\mathrm{E}$ these are the North and the East European Platform, in the S the Moesian Platform and the Dinarides, and the Eastern Alps and the Bohemian Massif in the W.

\subsection{Input databases}

Topography has been taken from the GTOPO30 database (Gesch et al., 1999). A map of the Carpathian-Pannonian Basin topography including the area of Southern and Eastern Europe is shown in Fig. 1.

Geoid data (Fig. 2) are taken from the EGM-2008 global model (Pavlis et al., 2008). In order to avoid effects of sublithospheric density variations on the geoid, we have removed the geoid signature corresponding to the long-wavelength component of the geoid up to degree and order 10 (Bowin, 1991).

\section{Modelling results}

The 1D modelling provides a very fast but preliminary view of the lithosphere structure (Grinč, 2013). Since the reference geoid $N_{0}$ (see Eq. 2) is a free parameter, we tested different models with different reference geoids (Table 1, Fig. 3 and Fig. 5). Depending on the value of $N_{0}$ used, the positions of maxima and minima of Moho and LAB depths are similar, but the absolute values change considerably. Therefore, the method needs independent observations on Moho depth in order to be calibrated.

In our study, the best results (good fit in the Vrancea zone with Hauser et 


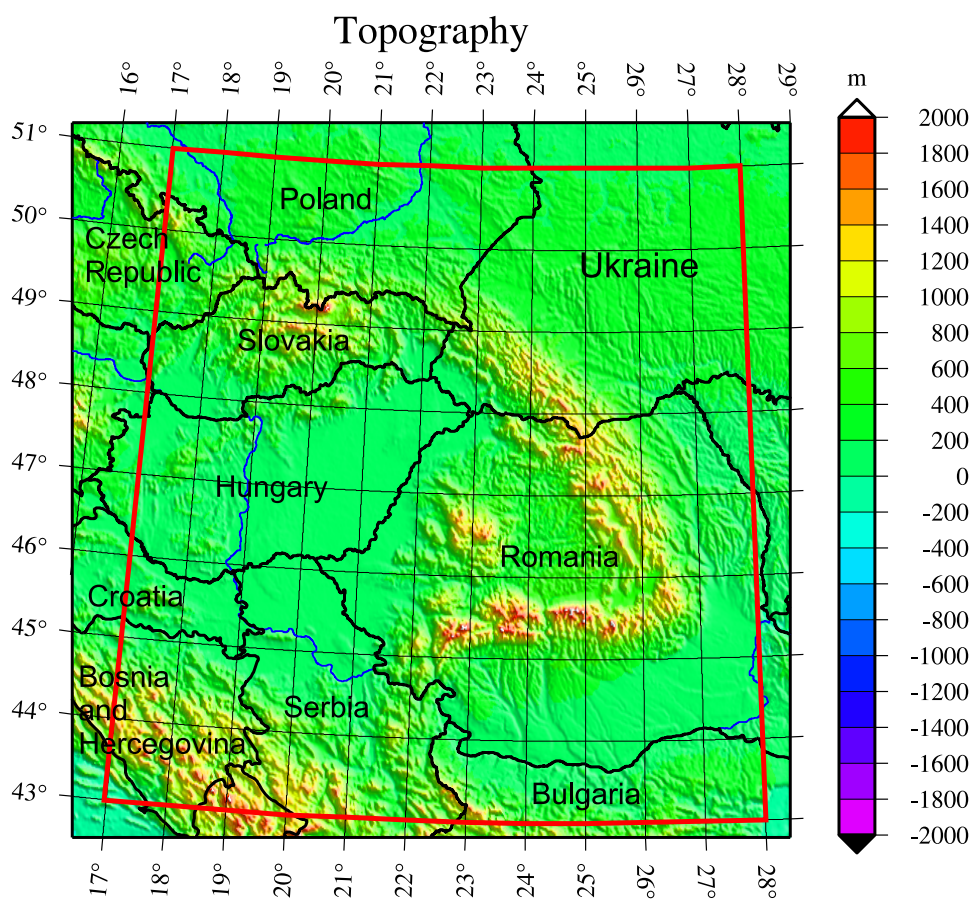

Fig. 1. Topography of the Central European region (from GTOPO30 data set, Gesch et al., 1999). The red rectangle shows the interpreted 1D area. The blue lines show main river flows of the study area.

al. (2007) reinterpretation of Vrancea99) were obtained by using the input parameters shown in the Table 2. These settings also satisfy our expectations about the Moho and the LAB in the regions (Fig. 4 and 6). The Moho depth map shows significant crustal thickness variations (Fig. 4) within the

Table 1. Values used for different reference geoid models (Fig. 3 and 5)

\begin{tabular}{|c|c|c|c|c|c|}
\hline symbol & parameter & model A & model B & model C & model D \\
\hline$\rho_{c}$ & Average crustal density & $2840 \mathrm{~kg} \mathrm{~m}^{-3}$ & $2860 \mathrm{~kg} \mathrm{~m}^{-3}$ & $2850 \mathrm{~kg} \mathrm{~m}^{-3}$ & $2850 \mathrm{~kg} \mathrm{~m}^{-3}$ \\
\hline$z_{c}$ & Moho depth of the ref. column & $28 \mathrm{~km}$ & $28 \mathrm{~km}$ & $27 \mathrm{~km}$ & $29 \mathrm{~km}$ \\
\hline$\rho_{\mathrm{a}}$ & density of the asthenosphere & \multicolumn{4}{|c|}{$3200 \mathrm{~kg} \mathrm{~m}^{-3}$} \\
\hline$\rho_{w}$ & Density of Water & \multicolumn{4}{|c|}{$1030 \mathrm{~kg} \mathrm{~m}^{-3}$} \\
\hline$z_{\max }$ & The compensation level depth & \multicolumn{4}{|c|}{$300 \mathrm{~km}$} \\
\hline
\end{tabular}




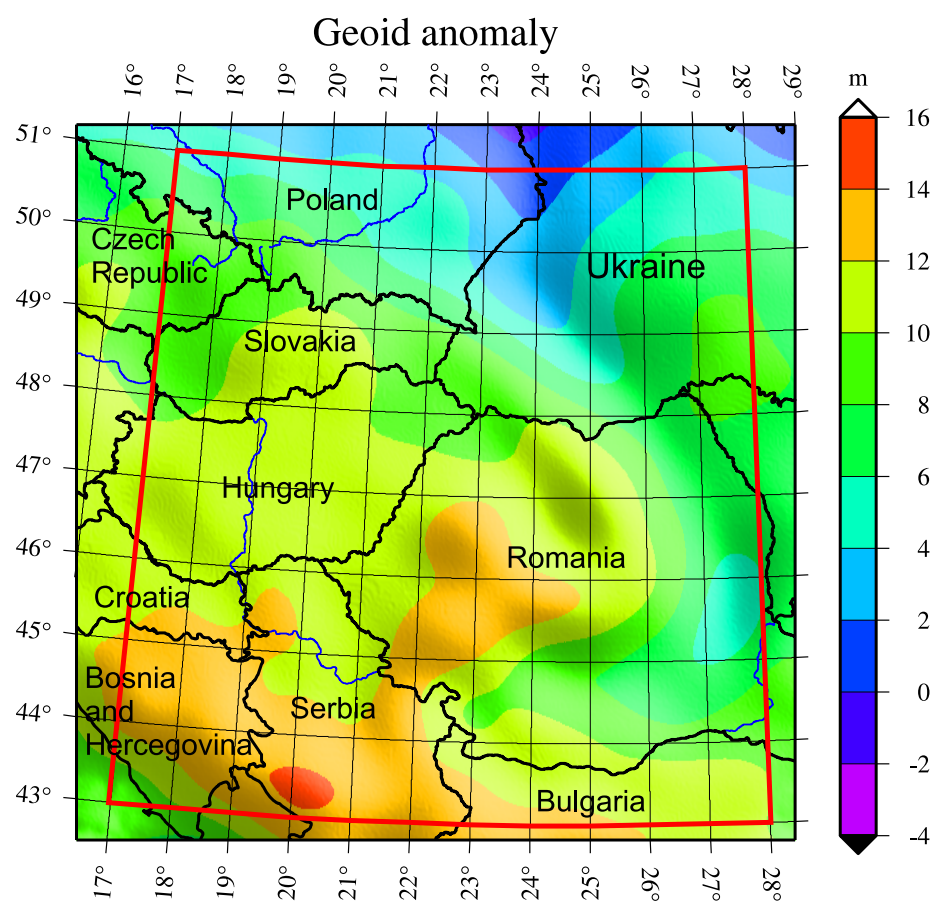

Fig. 2. Geoid anomaly map of the Central European region (from the EGM 2008 dataset (Pavlis et al., 2008) after removing the spherical harmonics until degree and order 10). The red rectangle shows the interpreted $1 \mathrm{D}$ area. The blue lines show main river flows of the study area.

studied area, what can be expected based on the many previous studies of the area (e.g. Zeyen et al., 2002; Bielik et al., 2004; Dérerová et al., 2006; Csicsay, 2010; Janik et al., 2011; Hauser et al., 2001, 2007; Mocanu

Table 2. Parameter values that satisfy our expectations about the Moho and the LAB of the region (Figs. 4 and 6)

\begin{tabular}{|c|c|c|}
\hline symbol & parameter & value \\
\hline$\rho_{c}$ & Reference average crustal density & $2850 \mathrm{~kg} \mathrm{~m}^{-3}$ \\
\hline $\mathrm{z}_{\mathrm{c}}$ & Moho depth of the reference column & $28 \mathrm{~km}^{-3}$ \\
\hline$\rho_{\mathrm{a}}$ & density of the asthenosphere & $3200 \mathrm{~kg} \mathrm{~m}^{-3}$ \\
\hline$\rho_{\mathrm{w}}$ & Density of sea water & $1030 \mathrm{~kg} \mathrm{~m}^{-3}$ \\
\hline $\mathrm{z}_{\max }$ & The compensation level depth & $300 \mathrm{~km}$ \\
\hline
\end{tabular}




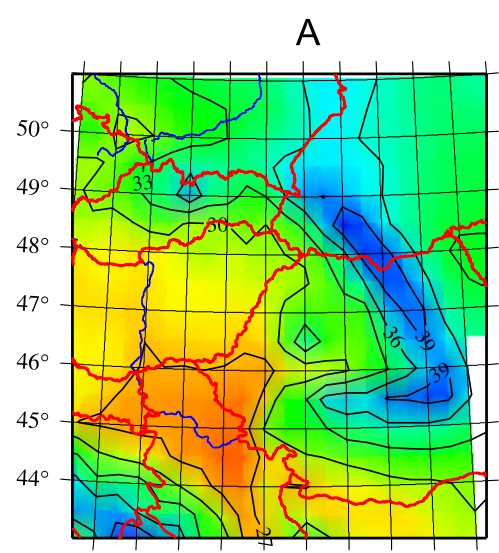

Moho 1D depth

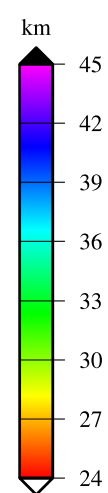

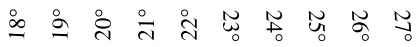

C

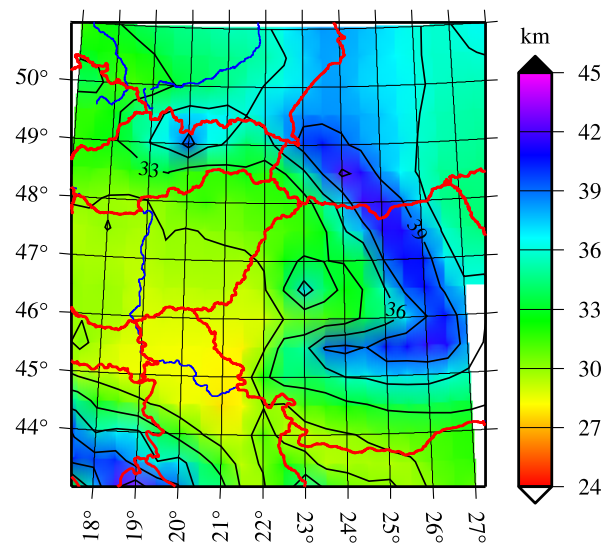

B

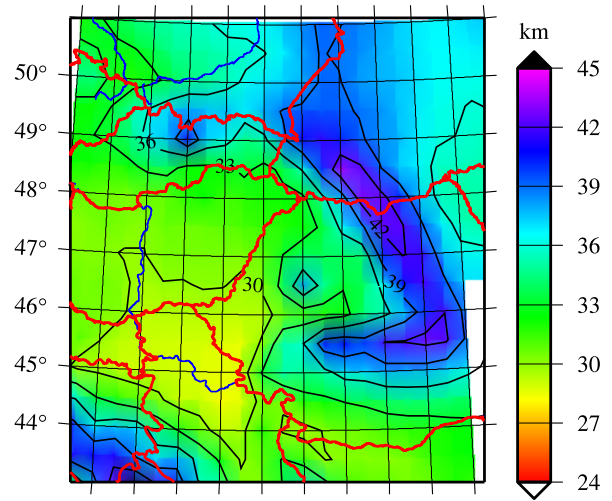

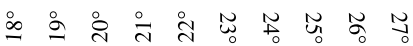

D

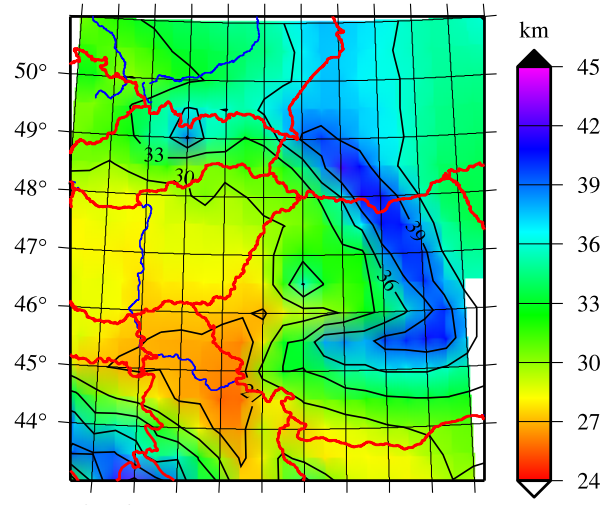

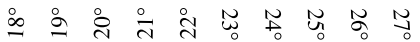

Fig. 3. 1D results for Moho depth in the Carpathian-Pannonian Basin region based on different reference geoids (see Table 1 for model parameters).

and Radulescu, 1994; Beránek and Zátopek, 1981; Guterch et al., 1986; Čekunov et al., 1988; Posgay et al., 1995; Tomek et al., 1987; Horváth, 1993; Alasonati-Tašárová et al., 2008, 2009). It can be seen that the crustal thicknesses increase from the Pannonian Basin towards the E and NE but the thickness of the crust does not fit well with the previous works in some parts of the studied area. The misfit can be caused by the used local isostasy 


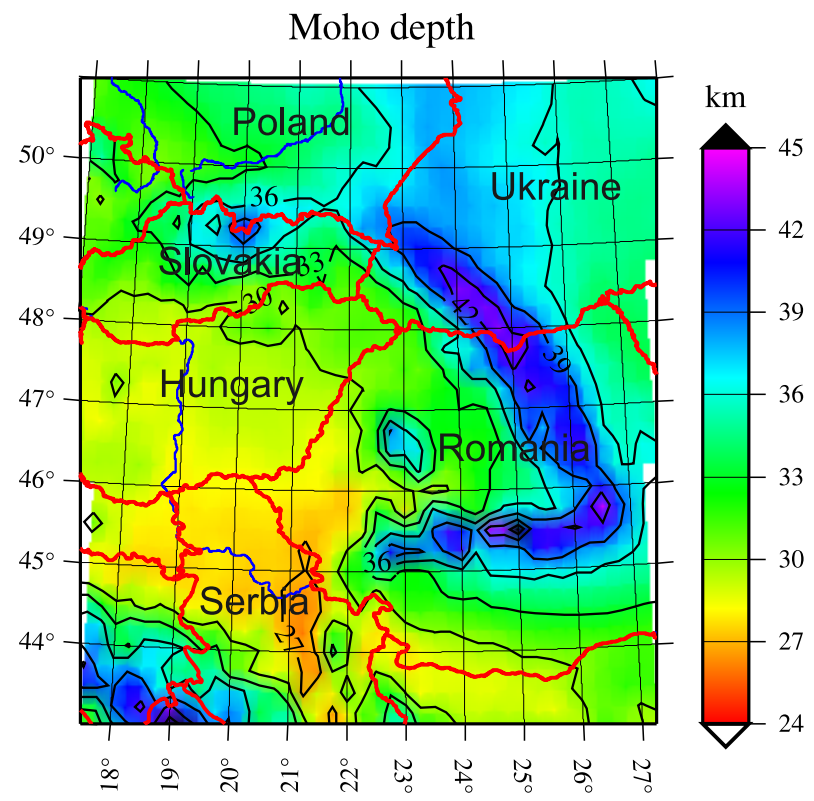

Fig. 4. 1D inversion result for Moho depth in the Carpathian-Pannonian Basin region (see Table 2 for model parameters and further explanation).

presupposition and by the 1D approach that is strictly valid only for longwavelength structures. It is very likely that the whole region is still not fully compensated, some tectonic processes are still going on and therefore the local isostasy cannot fully explain the topography of the region. The thickest crust is found underneath the Carpathian arc or its immediate Foredeep. Very high values are found in the Eastern Carpathians and Vrancea area $(44 \mathrm{~km})$. In defiance with the expectations, the thickest crust is found in a small area of the Southern Carpathians (more than $45 \mathrm{~km}$ ). The Dinarides crust also reaches in some parts more than $40 \mathrm{~km}$ thickness. The East European Platform is characterized by a crust with a thickness of about $34 \mathrm{~km}$. In the Apuseni Mountains, the depth of the Moho is about $36 \mathrm{~km}$. On the other hand, the Pannonian Basin and the Moesian Platform have thinner crust than the surrounding areas. Here we obtain crustal thicknesses of less than $30 \mathrm{~km}$ on average. The thinnest crust can be found in the SE part of the Pannonian Basin near the contact with Southern Carpathians where it is 
A

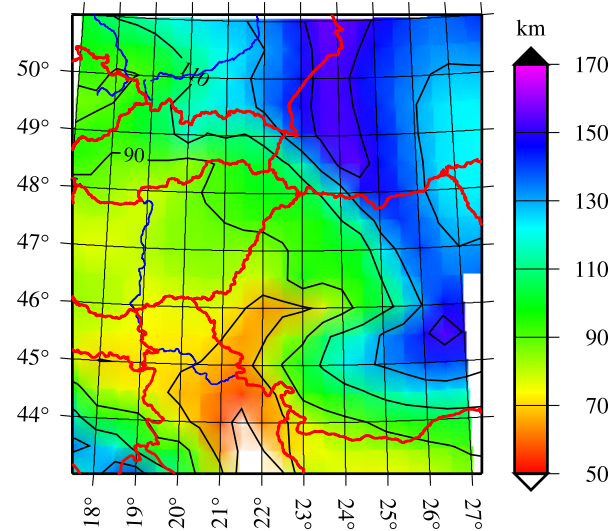

C

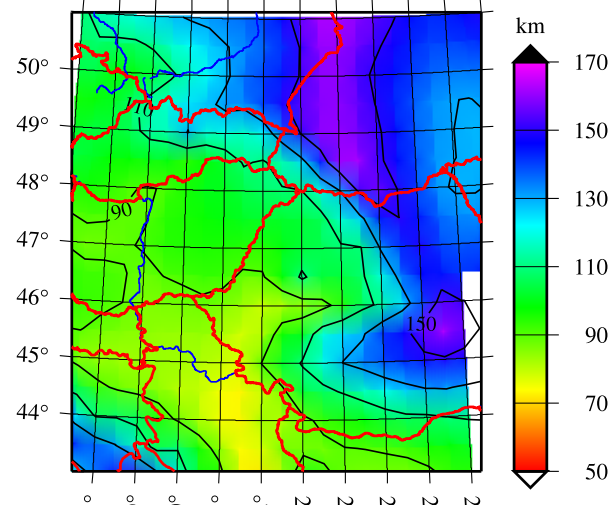

B

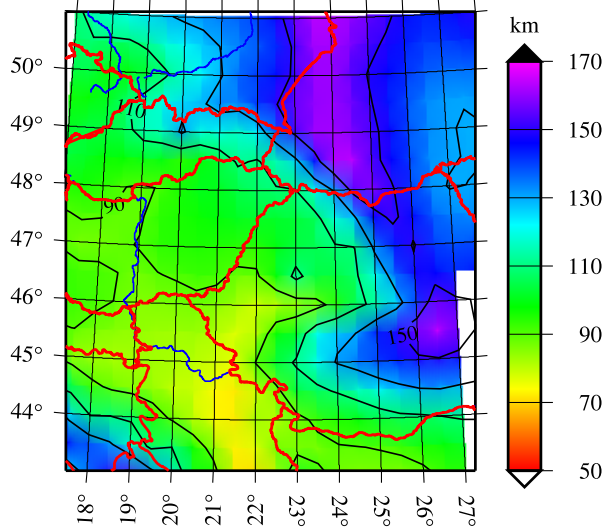

D

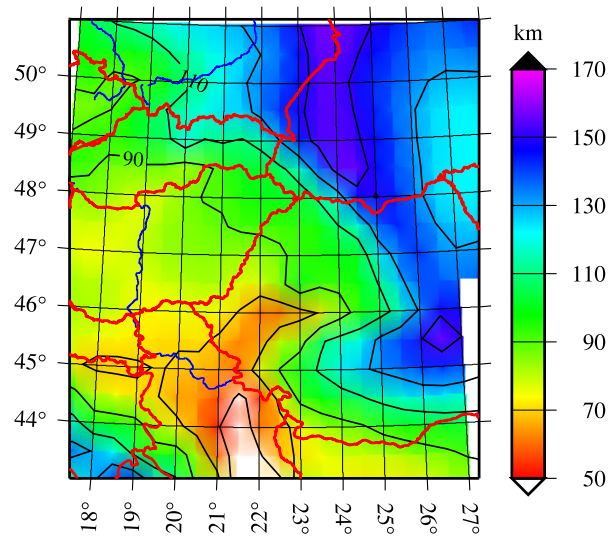

Fig. 5. 1D results for the LAB in the Carpathian-Pannonian Basin region based on different reference geoids (see Table 1 for model parameters).

only $26 \mathrm{~km}$. This result is surprising because the thinnest crust is expected in the central part of the Pannonian Basin (less than $25 \mathrm{~km}$ ) (Beránek and Zátopek, 1981; Guterch et al., 1986; Čekunov et al., 1988; Posgay et al., 1995; Tomek et al., 1987; Tomek and Hall, 1993; Horváth, 1993; Lenkey, 1999; Bielik et al., 2004; Dérerová et al., 2006; Csicsay, 2010), or even less $(22 \mathrm{~km})$ based on the interpretation of the CELEBRATION 2000 project (Janik et al., 2011). However, the southward thinning of the Pannonian 


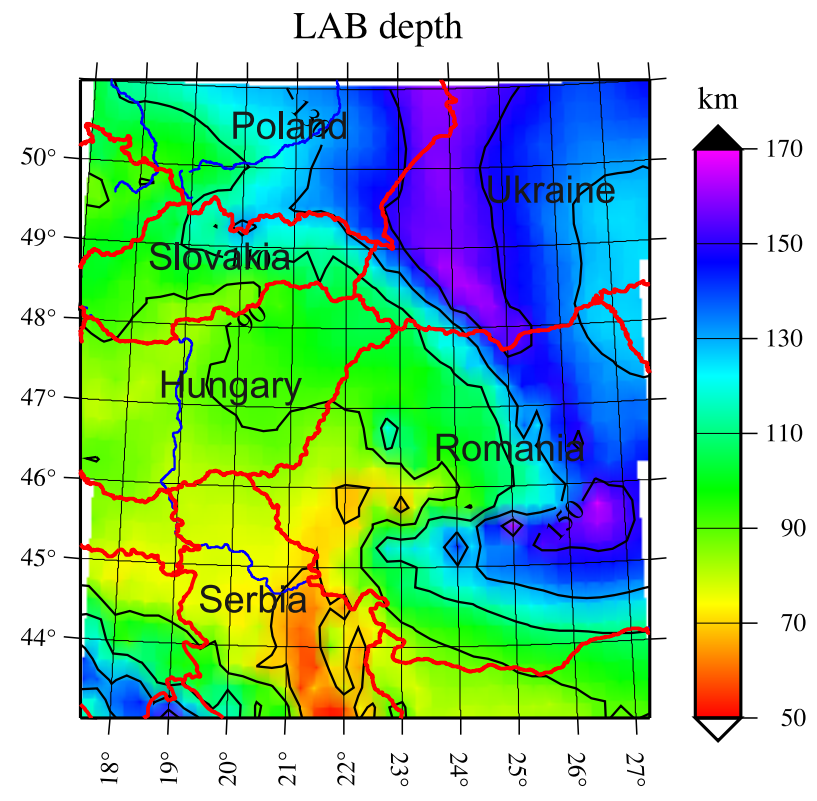

Fig. 6. 1D inversion model of the lithospheric thickness in the Carpathian-Pannonian Basin region (see Table 2 for model parameters and further explanation).

crust is consistent in all tested models.

The lithospheric thickness map shows also significant variations (Fig. 6). Again here we did not reach any extreme values of thinning or on the contrary thickening of the lithosphere. The thickest lithosphere is placed in the NE part of the map where the East European Platform, Eastern Carpathians and Southern Carpathians are located. The thickness of the lithosphere of the East European Platform is on average more than $120 \mathrm{~km}$ but in the northern part of this area some thicker places can be found. A strip of thicker lithosphere follows the Eastern Carpathians and its Foredeep where the values reach on average $160 \mathrm{~km}$. This result is in agreement with the results of Plomerová and Babuška (2010) and in contrast with the results obtained by Babuška et al. (1988), Horváth (1993), Šefara et al. (1996), Lenkey (1999), Dérerová et al. (2006), authors published values between $160 \mathrm{~km}$ and $240 \mathrm{~km}$. Especially in the Vrancea zone, a thicker lithosphere is expected. From here, the thickness of the lithosphere is decreasing towards 
the West where the thickness is less than $110 \mathrm{~km}$. The decreasing trend continues from here also towards the South and reaches a minimum at the southern border of the Southern Carpathians and in the SE part of the Pannonian Basin. Here, it is only $60 \mathrm{~km}$. The extremely low values of lithospheric thickness in this area were not shown before. The Moesian Platform is well delineated by a relatively thick lithosphere, characterized by an E-W trend of lithospheric thickness decrease. In the East, the thickness is about $110 \mathrm{~km}$ and in the west it is only $80 \mathrm{~km}$. The Pannonian Basin lithospheric thickness ranges from 80 to $100 \mathrm{~km}$ which is in accordance with Babuška et al. (1988), Horváth (1993), Šefara et al. (1996), Lenkey (1999), Zeyen et al. (2002), Dérerová et al. (2006) and Plomerová and Babuška (2010). The Dinarides in the SW part of the map show a maximum thickness of about $140 \mathrm{~km}$.

\section{Conclusion and discussion}

We used 1D approach as an initial estimate, a quick hands-on data, as a starting point for more detailed 2D and 3D studies (e.g. by laborious and tedious $2 \mathrm{D}$ and $3 \mathrm{D}$ integrated modelling). Joint modelling of geoid and topographic data allowed us to establish a very preliminary view into the lithospheric structure of the Carpathian-Pannonian Basin region and parts of their surrounding tectonic units. The 1D models show strong variations across the studied area and locates areas of relatively thin and relatively thick crust and lithosphere without giving solid absolute values. It can be observed at all our results that the lithospheric thickness increases from the Western Carpathians to the Eastern Carpathians along the strike. Our model reveals in general smaller differences between the thicknesses of the lithosphere under the North European Platform and the Pannonian Basin in comparison with previous results (Horváth, 1993; Lenkey, 1999). The large published lithospheric thicknesses north of the Western Carpathians (Horváth, 1993; Lenkey, 1999), in combination with a relatively thin crust $(<40 \mathrm{~km})$, would imply a topography below sea level.

One possibility to explain these differences is that a $1 \mathrm{D}$ model result is a smoothed model, since small depth changes have much larger 1D effects than the effects would be in a 3D model where those changes are laterally 
limited. Another potentially important factor is the assumption of constant average crustal density, since in areas with thick sedimentary cover the average crustal densities may be smaller, whereas in deeply eroded areas like the Precambrian platforms, they may be larger than average. Therefore, the results of models A and B (Figs. 3 and 5) may be more realistic for the Pannonian Basin and the European Platform respectively.

In addition, the programme calculates the topography based on the assumption of local isostasy which is an important restriction and has to be discussed. Part of the topography may be supported by elastic constraints if equivalent elastic plate thicknesses $(E E T)$ are too large. A few authors have analysed the EET of the different tectonic units of our region. Lankreijer et al. (1999) proposed very low values for the Polish Platform $(5-17 \mathrm{~km})$ and the Pannonian Basin $(5-10 \mathrm{~km})$. For the wavelengths we are concerned with (larger than 100-200 km), the elastic effects should then be small (e.g. Turcotte and Schubert, 1982). However, locally the elastic support and deformation may be important.

We have used geoidal heights in our study represented by short-wavelength component (above spherical harmonic degree and order 10) of the geoid, coined here as "geoid anomaly", in order to remove the signal of sublithospheric density distribution. Strictly speaking it cannot be guaranteed, that the density distribution within the lithosphere does not contribute into geoidal harmonics of up to degree 10, however, harmonics of degree 10 correspond to approximately $4000 \mathrm{~km}$ wavelength, which is much more than the size of our studied area of less than $100 \mathrm{~km}$. Therefore, only a linear gradient could be influenced by this effect.

Although our results differ locally quantitatively and qualitatively in comparison with the models calculated with different geoid settings, they show similar features in general. Lithospheric thickness increases from the eastern segment of the Western Carpathians, and reaches a maximum value in the Eastern Carpathians and in the Ukrainian and Romanian foreland. The area of the Southern Carpathians brings some controversial results and this area will need to be further tested.

Acknowledgments. This research has been supported by the French-Slovak bilateral PHC Stefanik (project No. 26331XG) and the Slovak-French bilateral APVV project (grant No. ESF-EC-0006-07). The first author is grateful to the Slovak Research and Development Agency, grant No. APVV-0194-10, for the support of this work. The 
authors acknowledge also partial support by the Slovak Grant Agency VEGA, grants No. 1/0095/12, and No. 2/0067/12.

\section{References}

Alasonati-Tašárová Z., Bielik M., Götze H.-J., 2008: Stripped image of the gravity field of the Carpathian-Pannonian region based on the combined interpretation of the CELEBRATION, 2000 data. Geologica Carpathica, 59, 3, 199-209.

Alasonati-Tašárová Z., Afonso J. C., Bielik M., Götze H. J., Hók J., 2009: The lithospheric structure of the Western Carpathian-Pannonian Basin region based on the CELEBRATION, 2000 seismic experiment and gravity modelling. Tectonophysics, 475, 3-4, 454-469.

Babuška V., Plomerová J., Pajdušák P., 1988: Lithosphere-asthenosphere in central Europe: Models derived from P residuals. In: Proc. 4th EGT Workshop: The Upper Mantle, Commission of the European Communities, European Science Foundation, Utrecht, Netherlands, 37-48.

Beránek B., Zátopek A., 1981: Earth's crust structure in Czechoslovakia and in Central Europe by methods of explosion seismology. In: Zátopek A. (Ed.), Geophysical syntheses in Czechoslovakia. VEDA, 243-270.

Bielik M., Šefara J., Kováč M., Bezák V., Plašienka D., 2004: The Western Carpathians interaction of Hercynian and Alpine processes. Tectonophysics, 393, 63-86.

Bowin C., 1991: The Earth's gravity field and plate tectonics. Tectonophysics, 187, 69-89.

Čekunov A. V., Ádám A. A., Blížkovský M., Bormann P., Guterch A., Dačev Ch., Kornea I., Kutas R. J., Magnickij V. A., Sollogub V. B., Chain V. E., Sollogub N. V., Starostenko V. J., 1988: Litosfera Centralnoj i Vostočnoj Evropy. Geotraversy I, II, V. Kiev, Naukova Dumka, 166 p. (in Russian).

Csicsay K., 2010: Two-dimensional and three-dimensional integrated interpretation of the gravity field based on international project CELEBRATION, 2000 data. Ph.D. thesis, Comenius University, Bratislava, 154 p. (in Slovak).

Dérerová J., Zeyen H., Bielik M., Salman K., 2006: Application of integrated geophysical modeling for determination of the continental lithospheric thermal structure in the eastern Carpathians. Tectonics, 25, 3, TC3009.

Fullea J., Fernàndez M., Zeyen H., 2005: Lithospheric structure in the Atlantic-Mediterranean transition zone: joint inversion of elevation and geoid anomalies. C. Geosciences, 338, 1-2, 140-151.

Fullea J., Fernàndez M., Zeyen H., 2006: Lithospheric structure in the Atlantic-Mediterranean transition zone (southern Spain, northern Morocco): a simple approach from regional elevation and geoid data. C. R. Geoscience, 338, 140-151.

Fullea J., Fernàndez M., Zeyen H., Vergés J., 2007: A rapid method to map the crustal and lithospheric thickness using elevation, geoid anomaly and thermal analysis. 
Application to the Gibraltar Arc System and adjacent zones. Tectonophysics, 430, 97-117.

Gesch D. B., Verdin K. L., Greenlee S. K., 1999: New land surface digital elevation model covers the Earth. EOS, Transactions American Geophysical Union, 80, 6, 69-70.

Grinč M., 2013: Lithospheric structure in Central Europe: integrated geophysical modelling. Ph.D. thesis, Comenius University, Bratislava, 178 p.

Guterch A., Grad M., Materzok R., Perchuč E., Toporkiewicz S., 1986: Results of seismic crustal studies in Poland. Publications of the Institute of geophysics Polish Academy of Sciences A-17. Państwowe wydawnictwo naukowe. Warszawa-Lódž, 192 p. (in Polish with English summary).

Hauser F., Raileanu V., Fielitz W., Bala A., Prodehl C., Polonic G., Schulze A., 2001: VRANCEA99 - the crustal structure beneath the south-eastern Carpathians and the Moesian Platform from a seismic refraction profile in Romania. Tectonophysics, 340, 3-4, 233-256.

Hauser F., Raileanu V., Fielitz W., Dinu C., Landes M., Bala A., Prodehl C., 2007: Seismic crustal structure between the Transylvanian Basin and the Black Sea, Romania. Tectonophysics, 430, 1-4, 1-25.

Haxby W. F., Turcotte D. L., 1978: On isostatic geoid anomalies, J. Geophys. Res., 83, 5473-5478.

Horváth F., 1993: Towards a mechanical model for the formation of the Pannonian Basin. Tectonophysics, 226, 333-357.

Janik T., Grad M., Guterch A., Vozár J., Bielik M., Vozárová A., Hegedüs E., Kovács C. A., Kovács I., Keller G. R., 2011: Crustal structure of the Western Carpathians and Pannonian Basin: seismic models from CELEBRATION, 2000 data and geological implications. Journal of Geodynamics, 52, 2, 97-113.

Lachenbruch A. H., Morgan P., 1990: Continental extension, magmatism and elevation; formal relations and rules of thumb. Tectonophysics, 174, 39-62.

Lankreijer A., Bielik M., Cloetingh S., Majcin D., 1999: Rheology predictions across the Western Carpathians, Bohemian Massif and the Pannonian Basin: implications for tectonic scenarios. Tectonics, 18, 6, 1139-1153.

Lenkey L., 1999: Geothermics of the Pannonian Basin and its bearing on the tectonics of basin evolution. Ph.D. thesis, Free University, Amsterdam, 215 p.

Mocanu V., Radulescu F., 1994: Geophysical features of the Romanian territory. Romanian Journal of Tectonics and Regional Geology, 75, 17-36.

Ockendon J. R., Turcotte D. L., 1977: On gravitational potential and field anomalies due to thin mass layers. Geophys. J. R. Astron. Soc., 48, 479-492.

Parsons B., Sclater J. G., 1977: An analysis of the variations of ocean floor bathymetry and heat flow with age. J. Geophys. Res., 82, 803-827.

Pavlis N. K., Holmes S. A., Kenyon S. C., Factor J. K., 2008: An Earth gravitational model to degree 2160: EGM2008, General Assembly of the European Geosciences Union, Vienna, Austria, April 13-18, 2008.

Plomerová J., Babuška V., 2010: Long memory od mantle lithosphere fabric - European LAB constrain from seismic anisotropy. Lithos, 120, 1-2, 131-143. 
Posgay K., Bodogy T., Hegedüs E., Kovácsvölgyi S., Lenkey L., Szafián P., Takács E., Tímár Z., Varga G., 1995: Asthenospheric structure beneath a Neogene basin in SE Hungary. Tectonophysics, 252, 467-484.

Šefara J., Bielik M., Konečný P., Bezák V., Hurai V., 1996: The latest stage of development of the Western Carpathian lithosphere and its interaction with asthenosphere. Geologica Carpathica, 47, 6, 339-347.

Tomek C., Hall J., 1993: Subducted continental margin imaged in the Carpathians of Czechoslovakia. Geology, 21, 535-538.

Tomek C., Dvořáková L., Ibrmajer J., Jiřičcek R., Koráb T., 1987: Crustal profiles of active continental collisional belt: Czecho-Slovak deep seismic reflection profiling in the Western Carpathians. Geophys. J . R. Astron. Soc., 89, 383-388.

Turcotte D. L., Schubert G., 1982: Geodynamics, J. Wiley \& Sons, New York, 450 p.

Zeyen H., Dérerová J., Bielik M., 2002: Determination of the continental lithosphere thermal structure in the Western Carpathians: integrated modelling of surface heat flow, gravity anomalies and topography. Physics of the Earth and Planetary Interiors, 134, 89-104. 